\title{
Economics of Hybrid Seed Production as Influenced by Staggered Sowing of Pollen Parent and Nitrogen Application to Seed Parent in Sunflower
}

\author{
Naganagouda Babagouda Patil ${ }^{1 *}$, Ashok S. Sajjan ${ }^{1}$, S. B. Patil ${ }^{2}$ and G. Uday ${ }^{3}$ \\ ${ }^{1}$ Department of Seed Science and Technology, ${ }^{2}$ ARS, Bagalkot, ${ }^{3}$ MARS, Dharwad, College of \\ Agriculture, Vijayapur, University of Agricultural Sciences, Dharwad, India \\ *Corresponding author
}

\section{A B S T R A C T}

K e y w o r d s
Seed parent (CMS-
78 A), Pollen parent
(RHA-78 R),
Application of
Nitrogen, Seed
yield,
Synchronization,
Gross returns, B:C
ratio
$\begin{aligned} & \text { Article Info } \\ & \text { Accepted: } \\ & 12 \text { November } 2020 \\ & \text { Available Online: } \\ & 10 \text { December } 2020\end{aligned}$

\section{Introduction}

Sunflower (Helianthus annuus L.) is an important edible oil seed crop of India popularly known as "surajmukhi". The crop is native to the temperate North America.

The genus name is associated with the characteristic heliotropism (turning towards Sun) exhibited by sunflower during the flowering period. Sunflower (Helianthus annuus L.) is one among the most important oil seed crops, ranking second in importance after soybean in the world.

Presently, it is cultivated in an area of 26.7 million hectares globally with production 51.95 million tonnes and productivity 1,948 $\mathrm{kg} \mathrm{ha}^{-1}$ (Anon., 2018). India is the largest grower of sunflower in the Asian subcontinent with an area of 0.28 million hectares and annual production of 0.22 million tonnes, and productivity of 782 $\mathrm{kg} \mathrm{ha}^{-1}$. The major sunflower producing states 
in India are Karnataka, Andhra Pradesh and Maharashtra. Karnataka is leading state in India contributing 64 per cent to the total area and 54 per cent to the total production and is popularly known as "sunflower state". In Karnataka, it is cultivated over an area of 0.17 million hectares with annual production and average productivity of 0.11 million tonnes and $618 \mathrm{~kg} \mathrm{ha}^{-1}$ respectively (Anon., 2018).

In the hybrid seed production, seed yield can be increased through proper synchronization of flowering of parental lines and optimum female to male parental rows. Synchronization in flowering between the parents in hybrid seed production is necessary to encourage optimum seed setting and desired higher seed yield. The parents may differ in flowering due to their genetic characters and differential response to change in environmental conditions. Under such a situation, the flowering time of the parental lines are required to be manipulated.

Hybrid seed production is influenced by several factors, such as planting ratio, nicking of flowering, pollen production and ability of restorer line, viability of pollens and duration of stigma receptivity, etc. When the difference in flowering of parents is more than marginal, the only alternative is to adopt staggered planting to achieve synchrony in flowering between the parents. This has been in practice since the release of hybrids. Staggered planting, a method in which male parent is sown in 2-3 splits, so that the flowering of male parent is adjusted to that of female parent, is being practiced widely by the seed growers in many hybrids of different crop plants to achieve proper synchronization of flowering between male and female parents. Synchronization of flowering of parental lines is one of the major constraints in any hybrid seed production programme. Whenever, the male parent being early in flowering compared to female parent is causing problem in realizing higher seed set, seed yield in hybrid seed production.

\section{Materials and Methods}

The seeds of both pollen and seed parents of KBSH-78 for the experiments were obtained from the AICRP on Sunflower, University of Agricultural Sciences, Bangalore. The experiment laid out in factorial randomized block design with three replications. The experiment consisted of eight treatment combinations, four staggered sowings $\left(\mathrm{S}_{1}\right.$ : Simultaneous sowing of pollen and seed parents, $\mathrm{S}_{2}$ : Seed soaking of pollen parent in $\mathrm{GA}_{3}$ for 18 hours, $\mathrm{S}_{3}$ :Sowing of pollen parent by 4 days late to seed parent and $S_{4}$ : Sowing of pollen parent by 6 days late to seed parent) and two nitrogen applications ( $\mathrm{A}_{1}: 2 \%$ nitrogen spray at button stage to seed parent and $\mathrm{A}_{2}$ : Application of $25 \mathrm{~kg}$ nitrogen per hectare at button stage to seed parent). The crop was planted in rabi season 2019 at Regional Agricultural Research Station, Vijayapur. Spacing of $60 \mathrm{~cm} \times 30 \mathrm{~cm}$ was followed in all the treatments. All the recommended package of practices was followed for higher seed yield. Seed yield was recorded per plot for each treatment after threshing and cleaning and weighed in grams and converted into yield per hectare in $\mathrm{kg}$.

The seed oil content (\%) from each treatment was estimated by using the Nuclear Magnetic Resonance (NMR) equipment on dry seed weight basis, expressed in per cent. Oil content was estimated in AICRP on Sunflower, UAS, Raichur. Oil yield per hectare was calculated based on the total oil content and the total oil yield per ha. The price of the inputs prevailed at the time of their use were taken for working economics of various treatments. Net income per hectare were calculated by deducting the cost of cultivation per ha from gross income per ha. 


\section{Results and Discussion}

The seed yield per hectare was found significantly higher when the male parent was sown six days later to the female parent (926 $\mathrm{kg} / \mathrm{ha}$ ). The higher seed yield of 40.82 per cent increased over control (548 kg/ha) followed by sowing of pollen parent by 4 days late to seed parent (795 kg/ha) (Table 1). This is due to proper synchronization in flowering of parental lines and availability of more pollens resulting in good seed set. These results are in accordance with the findings of Kamala et al., 1998 and Basavaraja and Malabasari 2014. The lower seed yield in the simultaneous sowing $\left(\mathrm{S}_{1}\right)$ of both parents $(548$ $\mathrm{kg} / \mathrm{ha}$ ), seed soaking of pollen parent in $\mathrm{GA}_{3}$ for 18 hours $\left(S_{2}\right)(583 \mathrm{~kg} / \mathrm{ha})$ and four days late sowing of pollen parent than the seed parent $\left(\mathrm{S}_{3}\right)(795 \mathrm{~kg} / \mathrm{ha})$ is due to lack of synchrony in flowering of parental lines and non-availability of pollens resulting in poor seed set. These results are in conformity with Kamala et al., (1998).

The superiority in the seed quality parameter like oil yield per ha (Table 1) in the seeds of six days $\left(\mathrm{S}_{4}\right)$ late sowing of pollen parent to the seed parent $(283 \mathrm{~kg} / \mathrm{ha})$ may be attributed due to better synchronization as a result of staggered sowing of seed and pollen parent resulted in increased seed yield per ha (926 $\mathrm{kg} / \mathrm{ha}$ ) in $\mathrm{S}_{4}$ than in other treatments. Better synchronization helped in complete filling of endosperm, which in turn resulted in improved seed quality. The similar results were reported in sunflower by Kamala et al., (1998), Turai et al., (2004) and Anagod (1994).

The economics of hybrid seed production in sunflower was influenced significantly due to the staggered sowing of seed and pollen parent (Table 2). Significantly maximum gross returns and net returns were recorded in sowing of pollen parent by 6 days late to seed parent (Rs. 92,667 and Rs. 69,210 respectively) followed by sowing of pollen parent by 4 days late to seed parent (Rs. 79,549 and Rs. 56,095 respectively). The lowest gross returns and net returns were recorded in simultaneous sowing of pollen and seed parent (Rs. 54,826 and Rs. 31,376 respectively). The higher $\mathrm{B}: \mathrm{C}$ ratio (3.95) was recorded in sowing of pollen parent by 6 days late to seed parent followed by sowing of pollen parent by 4 days late to seed parent (3.39). The lower $\mathrm{B}: \mathrm{C}$ ratio (2.34) was recorded in simultaneous sowing of pollen and seed parent. This might be due to increased seed yield and its contributing parameters and also less cost of cultivation and higher income. Similar results were also obtained byBasavaraja and Malabasari (2014).

The seed yield per hectare was found to be significantly higher when $25 \mathrm{~kg}$ nitrogen per ha was applied to seed parent at button stage (Table 1). The higher seed yield (732 kg/ha) of 5.19 per cent increased over 2 per cent nitrogen spray at button stage to seed parent (692 kg/ha). This may be due to the availability of sufficient nitrogen which matches the reproductive stage of the female parent with the male parent by delaying the vegetative stage by one or two days.Similar results were also obtained by Kamala et al., (1998) and Basavaraja and Malabasari (2014). Oil yield per ha was found to be significantly higher in $\mathrm{A}_{2}$ (Application of $25 \mathrm{~kg}$ nitrogen per ha at button stage to seed parent) (228 $\mathrm{kg} / \mathrm{ha}$ ) as compared to $\mathrm{A}_{1}$ (2 per cent nitrogen spray at button stage to seed parent) (216 $\mathrm{kg} / \mathrm{ha}$ ) (Table 1). This may be due to the availability of sufficient nitrogen which encourages the reproductive stage of the female parent with the male parent by delaying the vegetative stage by one or two days. This later resulted in synchronization of flowering between both the parents that lead to higher seed yield per hectare. Similar results were also obtained by Kamala et al., (1998) and Basavaraja and Malabasari (2014). 
Table.1 Effect of staggered sowing of pollen parent and nitrogen application to seed parent on seed yield per ha and oil yield per ha in sunflower hybrid KBSH-78

\begin{tabular}{|c|c|c|c|c|c|c|}
\hline \multirow{2}{*}{$\begin{array}{l}\text { Staggered } \\
\text { sowing (S) }\end{array}$} & \multicolumn{3}{|c|}{ Seed yield per ha $(\mathrm{kg} / \mathrm{ha})$} & \multicolumn{3}{|c|}{ Oil yield per ha (kg/ha) } \\
\hline & $\mathrm{A}_{1}$ & $\mathrm{~A}_{2}$ & Mean & $\mathrm{A}_{1}$ & $\mathrm{~A}_{2}$ & Mean \\
\hline $\mathbf{S}_{1}$ & 525 & 572 & 548 & 169 & 178 & 173 \\
\hline $\mathbf{S}_{2}$ & 575 & 591 & 583 & 181 & 185 & 183 \\
\hline $\mathbf{S}_{\mathbf{3}}$ & 770 & 820 & 795 & 243 & 257 & 250 \\
\hline $\mathbf{S}_{4}$ & 907 & 945 & 926 & 272 & 293 & 283 \\
\hline Mean & 694 & 732 & 713 & 216 & 228 & 222 \\
\hline $\begin{array}{c}\text { For comparing } \\
\text { means of }\end{array}$ & \multicolumn{2}{|l|}{ S.Em \pm} & $\mathrm{CD}$ at $(\mathrm{P}=0.05)$ & \multicolumn{2}{|c|}{ S.Em \pm} & $\mathrm{CD}$ at $(\mathrm{P}=0.01)$ \\
\hline $\mathbf{S}$ & \multicolumn{2}{|l|}{17.72} & 53.74 & \multicolumn{2}{|c|}{5.59} & 16.97 \\
\hline $\mathbf{A}$ & \multicolumn{2}{|l|}{12.53} & 38 & \multicolumn{2}{|c|}{3.96} & 12 \\
\hline $\mathbf{S} \times \mathbf{A}$ & \multicolumn{2}{|l|}{25.06} & & \multicolumn{2}{|c|}{7.91} & 24 \\
\hline
\end{tabular}

Note:

Staggered sowing of male parent (S)

$\mathrm{S}_{1}$ : Simultaneous sowing of pollen and seed parents

$\mathrm{S}_{2}$ : Seed soaking of pollen parent in $\mathrm{GA}_{3}$ for 18 hours

$\mathrm{S}_{3}$ : Sowing of pollen parent by 4 days late to seed parents

$\mathrm{S}_{4}$ : Sowing of pollen parent by 6 days late to seed parents

Application of nitrogen (A)

$\mathrm{A}_{1}: 2$ per cent nitrogen spray at button stage to seed parent

$\mathrm{A}_{2}$ : Application of $25 \mathrm{~kg}$ nitrogen per hectare at button stage to seed parent

Table.2 Effect of staggered sowing of pollen parent and nitrogen application to seed parent on economics in sunflower hybrid KBSH-78

\begin{tabular}{|c|c|c|c|c|c|c|c|c|c|}
\hline \multirow{2}{*}{$\begin{array}{l}\text { Staggered } \\
\text { sowing }(S)\end{array}$} & \multicolumn{3}{|c|}{ Gross return (Rs./ha) } & \multicolumn{3}{|c|}{ Net return (Rs./ha) } & \multicolumn{3}{|c|}{ B:C ratio } \\
\hline & $\mathrm{A}_{1}$ & $\mathrm{~A}_{2}$ & Mean & $\mathrm{A}_{1}$ & $\mathrm{~A}_{2}$ & Mean & $\mathrm{A}_{1}$ & $\mathrm{~A}_{2}$ & Mean \\
\hline $\mathbf{S}_{1}$ & 52,461 & 57,192 & 54,826 & 29,137 & 33,615 & 31,376 & 2.25 & 2.42 & 2.34 \\
\hline $\mathbf{S}_{2}$ & 57,442 & 59,048 & 58,245 & 34,100 & 35,454 & 34,777 & 2.46 & 2.50 & 2.48 \\
\hline $\mathbf{S}_{3}$ & 77,022 & 82,077 & 79,549 & 53,695 & 58,496 & 56,095 & 3.30 & 3.48 & 3.39 \\
\hline $\mathbf{S}_{4}$ & 90,720 & 94,614 & 92,667 & 67,390 & 71,031 & 69,210 & 3.89 & 4.01 & 3.95 \\
\hline Mean & 69,411 & 73,233 & 71,322 & 46,080 & 49,649 & 47,865 & 2.97 & 3.10 & 3.04 \\
\hline $\begin{array}{c}\text { For comparing } \\
\text { means of }\end{array}$ & \multicolumn{2}{|c|}{ S.Em \pm} & $\begin{array}{c}\mathrm{CD} \text { at } \\
(\mathrm{P}=0.05)\end{array}$ & \multicolumn{2}{|c|}{ S.Em \pm} & $\begin{array}{c}\mathrm{CD} \text { at } \\
(\mathrm{P}=0.05)\end{array}$ & \multicolumn{2}{|c|}{ S.Em \pm} & $\begin{array}{c}\mathrm{CD} \text { at } \\
(\mathrm{P}=0.05)\end{array}$ \\
\hline $\mathbf{S}$ & \multicolumn{2}{|c|}{$1,683.66$} & $5,106.85$ & \multicolumn{2}{|c|}{$1,659.84$} & $5,035.00$ & \multicolumn{2}{|c|}{0.06} & 0.17 \\
\hline A & \multicolumn{2}{|c|}{$1,190.52$} & $3,611.09$ & \multicolumn{2}{|c|}{$1,173.68$} & $3,560.00$ & \multicolumn{2}{|c|}{0.04} & 0.12 \\
\hline $\mathbf{S} \times \mathbf{A}$ & \multicolumn{2}{|c|}{$2,381.05$} & $7,222.17$ & \multicolumn{2}{|c|}{$2,347.37$} & $7,120.00$ & \multicolumn{2}{|c|}{0.08} & 0.24 \\
\hline
\end{tabular}

Note:

Staggered sowing of male parent (S)

$\mathrm{S}_{1}$ : Simultaneous sowing of pollen and seed parents

$\mathrm{S}_{2}$ : Seed soaking of pollen parent in $\mathrm{GA}_{3}$ for 18 hours

$\mathrm{S}_{3}$ : Sowing of pollen parent by 4 days late to seed parents

$\mathrm{S}_{4}$ : Sowing of pollen parent by 6 days late to seed parents

Application of nitrogen (A)

$\mathrm{A}_{1}: 2$ per cent nitrogen spray at button stage to seed parent

$\mathrm{A}_{2}$ : Application of $25 \mathrm{~kg}$ nitrogen per hectare at button stage to seed parent 
The economics of hybrid seed production in sunflower was influenced significantly due to the nitrogen application (Table 2). Significantly higher gross returns and net returns were recorded with application of 25 $\mathrm{kg}$ nitrogen per hectare at button stage to seed parent (Rs. 73,233 and Rs. 49,649 respectively). The lowest gross returns and net returns were recorded in 2 per cent nitrogen spray at button stage to seed parent (Rs. 69,411 and Rs. 46,080 respectively). The higher B:C ratio (3.10) was recorded with application of $25 \mathrm{~kg}$ nitrogen per hectare at button stage to seed parent and the lower B:C ratio (2.97) was recorded in 2 per cent nitrogen spray at button stage to seed parent. This might be due to increased seed yield and its contributing parameters and also less cost of cultivation and higher income. Similar results obtained byBasavaraja and Malabasari 2014.

The seed yield per hectare was found to be significantly higher due to interaction effects of nitrogen application and staggered sowing (Table 1). The higher seed yield $(945 \mathrm{~kg} / \mathrm{ha})$ of 44.44 per cent increased in sowing of pollen parent by 6 days late to seed parent along with application of $25 \mathrm{~kg}$ nitrogen per ha at button stage to seed parent $\left(\mathrm{S}_{4} \mathrm{~A}_{2}\right)$ over simultaneous sowing of pollen and seed parent along with 2 per cent nitrogen spray at button stage to seed parent $(525 \mathrm{~kg} / \mathrm{ha})$. This may be mainly due to availability of more pollens from staggered sowing of pollen parent resulted in better synchronization of parental lines and better seed set and availability of sufficient nitrogen which matches the reproductive stage of the female parent with the male parent by delaying the vegetative stage by one or two days. Similar results were also obtained by Umesh et al., 2007.

Oil yield per ha differed significantly due to interaction effect of nitrogen application to seed parent and the staggered planting of pollen parent (Table 1). The treatment combination $\mathrm{S}_{4} \mathrm{~A}_{2}$ recorded higher oil yield per ha $(293 \mathrm{~kg} / \mathrm{ha})$. This may be attributed to better synchronization of parental lines and better seed set helped to produce higher seed filling per cent, higher seed weight, seed yield per plot and per hectare. The increase in oil content due to application of $25 \mathrm{~kg}$ nitrogen per ha at button stage to seed parent can be explained in view of the fact that increased availability of nitrogen resulted in greater accumulation of proteins in plants and increased the availability of carbohydrates for polymerization into fatty acids, which in turn increased the oil content of seed. These results are in conformation withBasavaraja and Malabasari 2014 and Shakuntala et al., 2012.

The economics of hybrid seed production in sunflower was influenced significantly due to the interaction effect of staggered sowing and nitrogen application (Table 2). Significantly maximum gross returns, net returns and $\mathrm{B}: \mathrm{C}$ ratio were recorded in sowing of pollen parent by 6 days late to seed parent along with application of $25 \mathrm{~kg}$ nitrogen per ha at button stage to seed parent (Rs. 94,614, Rs. 71,031 and 4.01 respectively) followed by sowing of pollen parent by 6 days late to seed parent along with 2 per cent nitrogen spray at button stage to seed parent (Rs. 90,720, Rs. 67,390 and 3.89 respectively). The lowest gross returns, net returns and $\mathrm{B}: \mathrm{C}$ ratio were recorded in simultaneous sowing of pollen and seed parent along with 2 per cent nitrogen spray at button stage to seed parent (Rs. 52,461, Rs. 29,137 and 2.25 respectively). This might be due to increased seed yield and its contributing parameters and also less cost of cultivation and higher income. Similar results obtained byBasavaraja and Malabasari.

In conclusion the investigation revealed that, sowing of pollen parent by 6 days late to seed 
parent along with application of $25 \mathrm{~kg}$ nitrogen per hectare at button stage to seed parent resulted in better synchronization, enhanced seed yield and higher economics in sunflower hybrid KBSH-78.

\section{References}

Anagod, R.(1994).Studies on synchronization of flowering and planting ratio of parental lines in KBSH-1 hybrid sunflower seed production. M.Sc. (Agri.) Thesis, Univ. of Agric. Sci., Dharwad, Karnataka, India.

Anonymous, 2018, Indian statistical data on area, production and productivity of sunflower, 2018, www.indiastat.com.

Basavaraja and Malabasari, T. A. (2014).Effect of staggered sowing and nitrogen application on seed yield and quality of sunflower hybrid KBSH53.Int. J. Inf. Fut. Res., 12 (1): 107108.

Kamala, P. M.; ShaikMohammad and Lawrence, M. (1998). Influence of sowing date adjustment of parental lines and rate of nitrogen on synchronization of flowering, yield and seed quality of KBSH-1 sunflower hybrid. Crop Res., Hisar, 16(1): 123127.

Shakuntala, N. M.; Vyakaranahal, B. S.;Shankergoud, I. and Deshpande, V. K.(2012). Influence of planting ratios and staggered planting on seed yield and quality in hybrid seed production of sunflower hybrid RSFH-130. Karnataka J. Agric. Sci., 25(1): 52-57.

Turai, P. V.; Basave Gowda; Shekhargouda, M.; Vyakarnahal, B. S.;Nadaf, H. L. (2004). Flowering synchronization studies in DSH-1 sunflower hybrid (Helianthus annuus L.).Crop Res. Hisar, 27(2/3): 315-318.

Umesh, V. C.; Ravi Hunje; Nadaf, H. L.; Vyakarnahal, B. S. and Kanannavar, P. S. (2007). Studies on synchronization and seed set as influenced by locations, seasons and staggered planting in RSFH-1 sunflower hybrid. Karnataka J. Agric. Sci., 20(2): 257-260.

\section{How to cite this article:}

Naganagouda Babagouda Patil, Ashok S. Sajjan, S. B. Patil and Uday, G. 2020. Economics of Hybrid Seed Production as Influenced by Staggered Sowing of Pollen Parent and Nitrogen Application to Seed Parent in Sunflower. Int.J.Curr.Microbiol.App.Sci. 9(12): 1254-1259. doi: https://doi.org/10.20546/ijcmas.2020.912.154 